\title{
Protecting The Public AND OUR Physicians' INTERESTS: A PROPOSAL TO RECTIFY INCONSISTENCIES AND DEVELOP GuIDELINES ON PHYSICIANS' Disclosure of PATIENTS' HeAlth Data to ThIRD PARTIES IN THAILAND
}

\author{
Khajorndej Direksoonthorn* \\ Court of Appeal, Thailand \\ khajorndej.d@coj.go.th
}

This article argues for law reform in Thailand concerning the protection of health data, particularly laws involving the data's disclosure to third parties. It has been found that several pieces of Thai legislation governing this area are conflicting, causing confusion and disquiet to Thai physicians. Recently, Parliament has enacted the Personal Data Protection Act 2019. The said GDPR-style Act should have clarified all already-existing confusion regarding the inconsistency of legislation, but it has further complicated the matter instead. Doctors cannot disclose patients' health data to third parties, even to protect others or public interests. Court cases from other jurisdictions show that courts are willing to impose on physicians the duty to disclose patients' health data to third parties under certain circumstances, which makes the issue more significant to the Thai legal and medical communities. The article provides proposals to rectify the issue by amending relevant statutes and calling for professional guidance on this area which should be addressed by pertinent legislation. The relevant professional guidelines alongside the amended legislation will serve the interests of medical professionals, patients, and society at large.

Keywords: health data governance in Thailand, disclosure of patients' health data to third parties, physician's duty of health data disclosure

\footnotetext{
* Judge in the Research Justice Division, Court of Appeal, Thailand. M.D. (First Class Honors, Chulalongkorn University, Thailand), LL.M. (Rector's Award for Academic Excellence, Assumption University, Thailand), LL.M. (Harvard Law School, the United States). The author would like to thank Associate Professor Mark Taylor, Melbourne Law School, for encouraging him to publish this article, and the editors of the Columbia Journal of Asian Law for their editorial assistance. The views expressed in this article are those of the author and should not be attributed to any other member of the Thai judiciary.
} 
Health data governance in Thailand is still in its infancy. Many laws govern this area of data protection, including the National Health Act, B.E. 2550 (2007), which is the primary law tasked with promoting the health and well-being of the Thai people, and the Official Information Act, B.E. 2540 (1997), which covers the collecting, processing, and disclosing of personal information held by public authorities. However, the National Health Act seemingly contradicts other laws concerning health information protection in several contexts. These conflicts are compounded by the fact that Thai laws addressing the provision or disclosure of patients' information to third parties are not settled. Doctors and other health professionals cannot be certain that they are not running afoul of the law when disclosing their patients' information to others. Under current laws in Thailand, it is unclear whether doctors can disclose patients' genetic information to their genetic relatives. Professional guidance remains silent on the matter. This article will discuss the problems of health data governance in Thailand with particular regard to the physicians who practice medicine in Thailand.

The Ministry of Public Health of Thailand (MOPH) has apparently confused the issue. It has promulgated the 'Regulation on the Protection and Management of Personal Health Data, B.E. 2561 (2018).' Despite its status as a subordinate law, this Regulation contradicts its superior laws, the National Health Act and the Official Information Act. This Regulation strictly prohibits data disclosure which causes damage to the data subject. Accordingly, most doctors in the public sector and some in the private sector who share a health database with the MOPH cannot disclose patients' information to patients' genetic relatives or other third parties without contravening the Regulation.

This article will then turn to the comparative aspect of the issue to illuminate the problem in Thailand. It will explore the laws and court cases in other countries with advanced health data protection, namely the United Kingdom, the United States, and Australia, focusing on physicians' disclosure of patients' health data to third parties, including patients' genetic relatives. Courts in these countries are willing to impose on the doctor the duty to disclose the patient's health data to third parties in certain circumstances.

However, at least initially, it appears that doctors can pin their hopes on the advent of a new law entitled 'Personal Data Protection Act, B.E. 2562 (2019)' to clarify their legal obligations regarding the confidentiality of their patients' 
information. Unfortunately, the Thai Government postponed the Act's enforcement date for some entities, including those involved in medicine and public health, until 1 June 2021. The new law will not alleviate the problem until then at the earliest. Nor will it help elucidate the matter even then. Rather, it will probably make the existing problem obscurer and more complex, especially with respect to health data that may be disclosed to third parties or genetic relatives. This article will explore these problems by comparing the Personal Data Protection Act and its origin, the EU General Data Protection Regulation (GDPR).

In order to rectify the situation in Thailand, the author proposes amendments to the National Health Act and the MOPH's Regulation, which would eliminate the confusion arising from the conflicts they have with other legislation. However, the duty to warn third parties, if the Thai courts would impose it, should accord with professional guidance developed by the relevant professional bodies. A paucity of such professional guidance in Thailand has troubled doctors in their practice and demanded that they exercise discretion and professional judgement at their own risk. Furthermore, contradicting internal policies of different institutions make health data protection inconsistent throughout the country. Clear guidelines would ameliorate inconsistent policies by providing criteria for sound judgement about the disclosure to third parties.

The author also proposes amendments to the Personal Data Protection Act, supposedly the main data protection regime in Thailand in the near future, so that disclosure to third parties in certain circumstances would be allowed, and professional guidance would be issued in accordance with the Act. The relevant professional guidelines alongside the new personal data protection legislation would serve the interests of both medical professionals and patients as well as society at large.

\section{DOCTOR's DUTY OF CONFIDENTIALITY IN THAILAND}

Doctors in Thailand have long observed the duty of confidentiality. ${ }^{1}$ This duty has the same origin as its Western counterparts, ${ }^{2}$ that is, the Hippocratic oath. The Hippocratic oath in relevant part states:

\footnotetext{
${ }^{1}$ Sakda Sathirareuangchai, (การรักษาความลับของผู้ป่วย) [Duty of Confidentiality], 6(2) (เวชบันทึกศิริราช.) [SIRIRAJ MED. BULL.] 78, 78 (2013) (Thai.).

2 See The Ministry of Public Health's Regulation on the Protection and Management of Personal Health Data, B.E. 2561 Article 4 (2018) (Thai.).
} 
What I may see or hear in the course of the treatment or even outside of the treatment in regard to the life of men, which on no account one must spread abroad, I will keep to myself holding such things shameful to be spoken about. ${ }^{3}$

This duty has been believed to forge the doctor-patient relationship, which is premised on trust. Patients can trust their doctors as long as their revealed information are kept secret. ${ }^{4}$ Due to the characteristics of health data, they can immensely impact the data's owners. Data may cause embarrassment to their owner or even people related to the owner, such as data on infection of transmissible diseases. ${ }^{5}$ This can obviously be seen in the wake of the COVID-19 pandemic. Data may reflect intimate relationships between people they would like to keep secret. Closely related to the concept of the duty of confidentiality is the concept of privacy. The two concepts are fundamentally distinct from each other, especially in Western societies. ${ }^{6}$ Regarding the concept of privacy, in the simplest of terms, people have reasonable expectations in certain situations. For instance, people may not reasonably expect their conversion in public places to be recorded, but they may have that expectation in their own home arguably. Subsumed under the concept of privacy is informational privacy. ${ }^{7}$ Information privacy involves "the establishment of rules governing the collection and handling of personal data such as credit information, and medical and government records. It is also known as 'data protection.",

In order to comprehensively understand health data governance in Thailand, statutes and regulations that govern both respects of the system, namely the physician's duty of

\footnotetext{
${ }^{3}$ Lewis Vaughn, Bioethics: Principles, Issues, and Cases 83 (3d ed. 2017).

${ }^{4}$ Mark A Hall, Mary AnNe Bobinski \& DaVid ORentlicher, Medical LIABILITY AND TREATMENT RELATIONSHIPS 169-71 (Wolters Kluwer Law \& Bus., 3d ed. 2013).

${ }^{5}$ Raanan Gillon, Confidentiality, in A CoMPanion to Bioethics 425, 42531 (Helga Kuhse \& Peter Singer eds., Blackwell 1st ed. 1998).

${ }^{6}$ Ben White, Fiona McDonald \& Lindy Willmott, Health LaW in Australia 407 (3d ed., 2018).

${ }^{7}$ Mark Taylor, Genetic Data and the Law: A Critical Perspective ON PRIVACY PROTECTION 17 (2012).

8 Austl. L. Reform COMm', Report No. 108 Vol. 1, For Your INFORMATION: AUSTRALIAN PRIVACY LAW AND PRACTICE 142 (2008).
} 
confidentiality and informational privacy in relation to health data, should be thoroughly examined.

\section{A. Duty of Confidentiality}

The medical profession in Thailand is overseen by the Medical Council of Thailand (TMC). The TMC has been conferred several powers, including registering, issuing medical licenses, and controlling the conduct of medical practitioners so as to ensure that their conduct is in compliance with the ethics of the medical profession. ${ }^{9}$ Practicing physicians in Thailand need to observe the rules and regulations enacted by the TMC; otherwise disciplinary actions may ensue. ${ }^{10}$ The Code of Ethics for Doctors in Thailand provides: "A physician must not disclose their patient's secret which they obtained in a professional capacity unless the patient's lawful consent is given or that disclosure is required by law or duty." 11 The TMC, alongside other health care professional bodies, also issued the "Declaration of Patients' Rights" in 1998. Article 7 of the Declaration reads: "The patient has the right to expect that their personal information is kept confidential by the medical practitioner, the only exception being in cases with the consent of the patient or due to legal obligation." "Even though said Declaration is not the law, it reflects the initiative and intent of those professions. Moreover, apart from the moral or administrative binding, the Thai Supreme Court usually cite the professional organization's own regulations or initiatives to hold defendants liable when their conduct contradicts those provisions." $" 13$

Reflecting on those provisions, the duty of confidentiality on Thai physicians is quite strict. The doctor has few excuses to justify divulging the patient's information, including by receiving the patient's consent or having to disclose the information required by law and duty.

\footnotetext{
${ }^{9}$ See Medical Profession Act, B.E. $2525 \S \S 7,8$ (1982) (Thai.).

10 See Medical Profession Act, B.E. $2525 \S \S 31,32$ (1982) (Thai.).

${ }^{11}$ Medical Council's Rule on the Observance of the Code of Ethics, B.E. 2549

Article 27 (2006) (Thai.).

${ }^{12}$ The Declaration of Patients' Rights,

http://www.thaiclinic.com/pt_right.html (last visited Apr. 16, 2021) (Thai).

${ }^{13}$ Khajorndej Direksoonthorn, Informed Consent in Thailand: What Standard Is It? Which One Should It Be? 12(3) Asia PACIFIC J. OF HEALtH L. \& ETHICS 1,10 (2019).
} 


\section{B. Informational Privacy}

Both the right to privacy and the right to personal data protection are enshrined in the current Thai Constitution Section $32 .{ }^{14}$ Unlike the duty of confidentiality, personal data held by the public and private sectors are governed by several different legislative acts concerning informational privacy. Personal data held by the public sector is covered by the Official Information Act, B.E. 2540 (1997). ${ }^{15}$ This Act governs the collecting, processing, and disclosing of all personal information, including personal health information in possession or control of a governmental agency. ${ }^{16}$ Further, personal health information possessed by both the public and private sectors is also governed by the National Health Act, B.E. 2550 (2007).

An important subordinate law in this area is the Ministry of Public Health's Regulation on the Protection and Management of Personal Health Data, B.E. 2561 (2018). This Regulation concerns the disclosure of health data held by all entities under the control of the Ministry of Public Health. ${ }^{17}$ Therefore, the Regulation does not concern the entities under the oversight of other public authorities, such as university teaching hospitals overseen by relevant universities and Veterans Affairs hospitals supervised by the Thai Military.

\section{ThE PRoBlem OF CONFLICTING LAWS: ThE NATIONAL HEALTH ACT AND OTHER LAW}

The National Health Act, B.E. 2550 (2007), which has been in force since 2007, is the main piece of health care legislation and the first parliamentary Act to refer to 'personal

\footnotetext{
${ }^{14}$ Constitution of the Kingdom of Thailand, B.E. $2560 \S 32$ (2017) (Thai.) (A person shall enjoy the rights of privacy, dignity, reputation and family. An act violating or affecting the right of a person under paragraph one, or an exploitation of personal information in any manner whatsoever shall not be permitted, except by virtue of a provision of law enacted only to the extent of necessity of public interest.).

${ }^{15}$ See Official Information Act, B.E. 2540 (1997) (Thai.).

${ }^{16}$ Official Information Act, B.E. $2540 \S 4$ (1997) (Thai.) ("official information" means an information in possession or control of a State agency, whether it is the information relating to the operation of the State or the information relating to a private individual.).

${ }^{17}$ Ministry of Public Health's Regulation on the Protection and Management of Personal Health Data, B.E. 2561 Article 4 (2018) (Thai.) (defines a data controller as "all entities under the control of the Ministry as well as other entities, whether public or private, which wish to share the health database with the Ministry.").
} 
health information' clearly. ${ }^{18}$ However, the Act creates difficulties in its interpretation and enforcement. That may worry the physician when dealing with this kind of sensitive information. ${ }^{19}$

Section 7 of the Act reads: "Personal health information shall be kept confidential. No person shall disclose it in such a manner as to cause damage to him or her, unless it is done according to his or her will or is required by a specific law to do so. In any case whatsoever, no person shall have the power or right under the law on official information or other laws to request a document related to personal health information of any person other than himself or herself." 20 (emphasis added). The last sentence of the Section is problematic. To illustrate, the first part of the Section provides two exceptions to the duty of confidentiality, which justifies the physician's breach of confidence which correspond with the exceptions set forth in the Code of Ethics for Doctors in Thailand. ${ }^{21}$ The first exception is by consent given by the patient. The second is by the physician's legal duty required by specific laws such as the Official Information Act, the Communicable Diseases Act, and the Mental Health Act. ${ }^{22}$ However, the last sentence of the National Health Act strictly prohibits, without exception and regardless of any other law that may be invoked, a request for a document related to personal health information of any person other than the one requesting the document himself or herself.

The Official Information Act, B.E. 2540 (1997), which has been in force since 1997, covers the collecting, processing, and disclosing of personal information held by State Agencies. ${ }^{23}$

\footnotetext{
${ }^{18}$ Sathirareuangchai, supra note 1 , at 78 .

19 See Crime News Team, ดต.พ้องหมอเปิดเผยข้อมูลลูกเป็นเด็กดาวน์ฯ [Police Officer Alleges Doctor Disclosed His Child's Down Syndrome], MGR OnLINE (Jan. 15, 2013), https://mgronline.com/crime/detail/9560000005805.

${ }^{20}$ National Health Act, B.E. $2550 \S 7$ (2007) (Thai.).

${ }^{21}$ Medical Council's Rule on the Observance of the Code of Ethics, B.E. 2549 Article 27 (2006) (Thai.).

22 See Hathaichanok Raiwong, ปัญหาเกี่ยวกับการคุ้มครองข้อมูลส่วนบุคคลด้านสุขภาพ [Problems Relating to the Protection of Personal Health Information] 11(3) วารสารบัณฑิตศึกษานิติศาสตร์ [GRADUATE L. J.] 695 (2018) (Thai.).

23 See Official Information Act, B.E. 2540 Chapter III (1997) (Thai.) (According to Section 4 of the Act, "State agency" means a central administration, provincial administration, local administration, State enterprise, Government agency attached to the National Assembly, Court only in respect of the affairs unassociated with the trial and adjudication of cases, professional supervisory organization, independent agency of the State and such other agency as prescribed in the Ministerial Regulation.).
} 
Section 24 of this legislation prohibits disclosure of personal information without prior or immediate consent given in writing by the person who is the subject thereof except for disclosure in certain circumstances. ${ }^{24}$ Such exceptions include the disclosure in ordinary use of the information within the objectives of the provision for such personal information system ${ }^{25}$, and the disclosure to the court, state officials, state agencies or persons having power under law to make a request for such information. ${ }^{26}$ It turns out, pursuant to Section 7 of the National Health Act, even Thai courts cannot request or subpoena a document related to personal health information other than that of the person who requests or subpoenas.

Likewise, the Communicable Diseases Act, B.E. 2558 (2015), which has been in effect since $2016^{27}$, stipulates notifiable diseases. Section 31 of the Act imposes on certain persons the duty to notify a communicable disease control officer of the occurrence of a dangerous communicable disease, a communicable disease under surveillance or an epidemic, all of which are enumerated in the Act. ${ }^{28}$ Section 34 of the same Act then grants communicable disease control officers the power to require persons who are infected or reasonably suspected of being infected with the dangerous communicable disease or epidemic, or are contacts or carriers, to have a check-up or treatment or medical examination. In addition, for the purpose of safety, such persons may be isolated, quarantined or controlled for observation at places specified by communicable disease control officers until such persons have had a checkup and medical examination and it is confirmed that the period of communicability has passed, or such suspicion has been dispelled. ${ }^{29}$ In those circumstances, it may be the case that

${ }^{24}$ Official Information Act, B.E. $2540 § 24$ (1997) (Thai.) (A State agency shall not disclose personal information in its control to other State agencies or other persons without prior or immediate consent given in writing by the person who is the subject thereof except for the disclosure in the following circumstances...).

${ }^{25}$ Official Information Act, B.E. $2540 § 24(2)$ (1997) (Thai.).

${ }^{26} I d . \S 24(8)$.

${ }^{27}$ Communicable Diseases Act, B.E. 2558 \& 2 (2015) (Thai.) (Section 2 of the Act reads: 'This Act shall come into force after the expiration of one hundred and eighty days from the date of its publication in the Government Gazette.' It was published in the Government Gazette on September $8^{\text {th }}$, 2015).

${ }^{28} \mathrm{Id}$. $\S 31$ (In the case of occurrence of a dangerous communicable disease, a communicable disease under surveillance or an epidemic, the following persons shall notify a communicable disease control officer....).

${ }^{29} I d$. § 34 (For the purpose of prevention and control of communicable diseases, when a dangerous communicable disease or an epidemic has 
communicable disease control officers may request, from relevant health care professionals or institutions, documents concerning the personal health information of the persons who are infected or suspected of being infected with the specified categories of communicable diseases. However, pursuant to the last sentence of Section 7 of the National Health Act, the communicable disease control officer concerned cannot request such a document without any exception.

By the same token, the Mental Health Act, B.E. 2551 (2008), which has been in force since 2008, provides a legal framework for treatment of a person with mental disorders to protect the theirs and society as a whole's safety. Section 16 of the Act provides that no person shall disclose health information of a patient in such a way that is likely to cause damage to the patient, except (1) in a case where harm may be caused to the patient or to others; (2) for the safety of the public; (3) where there is a special law prescribing the disclosure. Therefore, a psychiatrist may be requested to produce a document related to a patient's personal health information after informing the relevant parties for the safety of the public or due to special laws. Again, it turns out that such a request or production of document is strictly prohibited by the Section 7 of the National Health Act.

In sum, the formulation of Section 7 of the National Health Act has caused confusion and concern to physicians practicing in Thailand. Considering the right to personal information is recognized in the Constitution, and the Code of Ethics for doctors in Thailand prescribes a strict duty of confidentiality for doctors, the inconsistencies and uncertainty caused by Section 7 of the National Health Act may render the disclosure of the patient's health data to third parties practically prohibitive. ${ }^{30}$

Furthermore, the laws on doctors' disclosure to third parties have been deficient, complicating the aforementioned matters more. Next, this article will discuss the disclosure of patient information to third parties to demonstrate physicians' lack of certainty regarding disclosures.

occurred or is suspected of having occurred in any area, a communicable disease control officer in such area shall have the power to carry out, or issue a written order instructing any person to carry out the following....).

${ }^{30}$ See generally Medical Dilemma II: Confidentiality, Patient's Rights and Medical Ethics, หมอชาวบ้าน [Thai Traditional Medicine] (Oct. 1, 2007), https://www.doctor.or.th/clinic/detail/7453 (Pointing out the uncertainty Thai doctors confront in general when revealing patients' information to others). 


\section{The Disclosure of PATIENT DATA to ThIRD PARTIES: DEFICIENCIES OF LAW AND GUIDANCE}

The internal inconsistency contained in the National Health Act and its conflicts with other relevant laws as discussed above are further compounded by doctors' duty to third parties. Medical malpractice law in Thailand is still highly underdeveloped. ${ }^{31}$ Apparently, only a few relevant textbooks exist not to mention the fact that those have been written only in the Thai language. It has been claimed that judges in Thailand have "few sources of guidance in malpractice cases, as there are very few statutes, books, or articles that discuss malpractice jurisprudence." 32 Few precedents from the Supreme Court of Thailand are ascertainable to guide trial judges in adjudicating a medical malpractice case. ${ }^{33}$ The standard of care for medical malpractice is unsettled. ${ }^{34}$ In one court case, the Supreme Court of Thailand used testimony from a general practitioner, notably not a pediatrician, to speak to the standard of care in pediatric treatment. ${ }^{35}$ As a result, physicians in Thailand may find it difficult, if not impossible, to base their informed judgement upon guidance about their legal duty to third parties from court rulings. Arguably, health care professionals can look to their professional guidelines and assume that the respective guidelines accord with the law. ${ }^{36}$ Yet, the Medical Council of Thailand is silent on the matter regarding disclosure to third parties. The Code of Ethics for Doctors is quite rigid with respect to the duty of confidentiality. ${ }^{37}$ According to the Code, doctors in Thailand can breach the duty of confidentiality on only two grounds: when the disclosure is required by law or required by duty. ${ }^{38} \mathrm{We}$ have discussed the requirements for disclosure required by law, e.g., disclosure requirements for notifiable diseases. However,

\footnotetext{
${ }^{31}$ Nathan Cortez, Recalibrating the Legal Risks of Cross-Border Health Care 10 YAlE J. OF HEALTH POL'Y, L., AND ETHICs 1, 43 (2010).

32 Nathan Cortez, A Medical Malpractice Model for Developing Countries? 4 DREXEL L. REV. 217, 228 (2011).

${ }^{33}$ Yot Teerawattananon et al., Health Sector Regulation in Thailand: Recent Progress and the Future Agenda 63 HeAlTH POLICY 323 (2003).

34 Tanaroj Lortanapaisan, ปัญหากฎหมายเกี่ยวกับการคุ้มครองสิทธิผู้เสียหายจากบริการทางการแพทย์: กรณีศึกษาเปรียบเทียบในอาเซียน [Legal Problems in Protecting Injured People's Rights Arising from Medical Services: A Comparative Study of ASEAN Countries] 10 วารสารนิติศาสตร์ มหาวิทยาลัยอัสสัมชัญ [ASSUMPTION U. L. J.] 138, 142 (2019).

35 คำพิพากษาศาลฎีกาที่ ๑๒๔ะส/๒๕๕๕ (2015) Thai. Sup. Ct. No. 12498/2558.

36 Jonathan Herring, MedicAl LAW AND Ethics 237-8 (7th ed. 2018).

${ }^{37}$ See The Medical Council's Rule on the Observance of the Code of Ethics, B.E. 2549 Article 27 (2006) (Thai.).

${ }^{38}$ Id.
} 
requirements for disclosure required by duty have never been clarified by any guidance or guidelines. ${ }^{39}$ The Medical Council has never expounded this issue. Given the uncertainties due to the confusingly conflicting laws, it is doubtful that, without patient consent, physicians would decide to divulge patients' confidential information to third parties to protect the third parties, the public at large or other public interest. ${ }^{40}$

It should be noted that, generally speaking, there are currently no law nor professional guidance prescribing physicians' duty to disclose the patient health data to others in order to protect third parties or other public interest in Thailand. ${ }^{41}$ The few exceptions are to report child abuse ${ }^{42}$ or notifiable diseases ${ }^{43}$ to relevant competent officials. Therefore, virtually all laws on the issue exist to justify doctors' breach of confidence in disclosing patient health information rather than to obligate the doctor to breach the duty of confidentiality. To the author's knowledge, there are no court cases associated with the duty to disclose the patient's confidential information to third parties or genetic relatives in Thailand.

Court cases from other jurisdictions merit further exploration to shed light on the likelihood of Thai courts

\footnotetext{
${ }^{39}$ One of the fundamental objectives of the Medical Council of Thailand, according to the Medical Profession Act, B.E. 2525 (1982) section 7, is to control conduct of medical practitioners so as to be in compliance with the ethics of the medical profession. Accordingly, the Medical Council has the power, under section 21 of the said Act, to issue any rules and guidelines on such relevant matters.

${ }^{40}$ Medical Dilemma II: Confidentiality, Patient's Rights and Medical Ethics, supra note 30.

${ }^{41}$ Sathirareuangchai, supra note 1, at 80; See also Official Information Act, B.E. $2540 \S 24$ (1997) (Thai.); Mental Health Act, B.E. $2551 \S 16$ (2008) (Thai.).

${ }^{42}$ Child Protection Act, B.E. $2546 \S 29$ (2003) (Thai.) (If it clearly appears or is suspected that a child has been tortured or is sick due to illegal care, a medical doctor, nurse, psychologist or public health official who admits a child for medical treatment or a teacher, instructor or employer having the duty to take care of a child as student or employee, shall report, without delay, the competent official or person having duty to provide welfare protection to a child under section 24 or the administrative official or police officer.).

${ }^{43}$ Communicable Diseases Act, B.E. $2558 \S 31$ (2015) (Thai.) (In the case of occurrence of a dangerous communicable disease, a communicable disease under surveillance or an epidemic, the following persons shall notify a communicable disease control officer: (1) in the case where a person infected or reasonably suspected of being infected with such communicable disease is found in a house, an owner of the house or a person in charge of the house or a physician who provides treatment; (2) in the case where a person infected or reasonably suspected of being infected with such communicable disease is found in a sanatorium, a person responsible for the sanatorium...).
} 
imposing on physicians the duty to disclose health data to third parties. If it is found that the judiciary is willing to impose such a duty, professional guidelines may be urgently needed for physicians to avoid liability.

This article will now turn to related court cases in other countries: the United States, the United Kingdom, and Australia.

\section{A. Physicians' Duty of Disclosure to Third Parties}

In the United States, Tarasoff v. Regents of University of California $^{44}$ was the first and arguably the most famous case in which the Supreme Court of California imposed a duty to disclose patient information on psychotherapists when their patients posed a serious threat to others. ${ }^{45}$ The Court laid down the oft-cited decision: "The [Psychotherapist's] revelation of a [patient's] communication[s] is not a breach of trust or a violation of professional ethics [where such disclosure is necessary to avert danger to others]...public policy favoring protection of the confidential character of patientpsychotherapist communications must yield to the extent to which disclosure is essential to avert danger to others. The protective privilege ends where the public peril begins." 46 (Emphasis added.) A therapist has a duty "to use reasonable care to protect [a potential victim when they determine], or under applicable professional standards reasonably should have determined, that a patient poses a serious danger of violence to others. ${ }^{47}$ However, the Californian Legislature has limited the Tarasoff decision by legislation. The Californian statute imposes a duty to a psychotherapist only if "the patient has communicated to the psychotherapist a serious threat of physical violence against a reasonably identifiable victim or victims." (Emphasis added.) $)^{48}$ "The statute represents 'a legislative effort to strike an appropriate balance between conflicting policy interests. On the one hand, the need to preserve a patient confidence recognizes that effective diagnosis and treatment of a mental illness or an emotional problem is severely undermined when a patient cannot be assured that a statement made in the

\footnotetext{
${ }^{44}$ Tarasoff v. Regents of University of California, 17 Cal. 3d 425, 551 P.2d 334 (1976).

${ }^{45}$ Wendy Nixson, Has the Right to Breach Patient Confidentiality Created A Common Law Duty to Warn Genetic Relatives? 17 QUT L. REV. 147, 155 (2017).

${ }^{46}$ Tarasoff, 17 Cal. 3d 425, 347.

${ }^{47} \mathrm{Id}$.

${ }^{48}$ Cal. Civ. Code $\S 43.92(a)$.
} 
privacy of his therapist's office will not be revealed. On the other hand, is the recognition that, under limited circumstances, preserving a confidence is less important than protecting the safety of someone whom the patient intends to harm." "49 Tarasoff is an important opinion, almost always cited by courts and legislative bodies whether it is followed or rejected..$^{50}$

As to the duty to third parties in non-mental disorder cases, the Supreme Court of Tennessee ruled that a physician owed a duty to warn a patient's wife of the risk of contracting Rocky Mountain spotted fever, a noncontagious disease, from the patient due to a phenomenon called clustering, the transmission of the disease to humans by infected ticks. ${ }^{51}$ Furthermore, "physicians have been held liable for failing to warn the daughter of a patient with scarlet fever, a wife about the danger of infection from a patient's wounds, and a neighbor about [a] patient's smallpox." 52

In the United Kingdom, the UK court appears to allow doctors to reveal patients' confidential information if it is necessary to protect the public interest in maintaining others' safety and welfare. ${ }^{53}$ The General Medical Council (GMC), a professional body which oversees the practice of medicine in the $\mathrm{UK}^{54}$, has issued relevant guidelines. The GMC's guidance on confidentiality states: "There can be a public interest in disclosing information if the benefits to an individual or society outweigh both the public and the patient's interest in keeping the information confidential. For example, disclosure may be justified to protect individuals or society from risks of serious harm, such as from serious communicable diseases or serious crime. ${ }^{55}$ However, 'it is far from clear whether [a therapist's obligation to use reasonable care to protect the victim set by Tarasoff] would be followed in England and Wales. The general

\footnotetext{
${ }^{49}$ Regents of Univ. of Cal. v. Superior Ct., 29 Cal. App. 5th 890, 240 Cal. Rptr. 3d 675, 686 (2018).

${ }^{50}$ Mary Anne Bobinski et AL, Bioethics and Public Health Law 151 (4th ed. 2018).

${ }^{51}$ Bradshaw v. Daniel, 854 S.W.2d 865 (Tenn, 1993).

52 BARry R FurRow ET AL, HEALTH LAW 208 ( $3^{\text {rd }}$ ed. 2015).

${ }^{53}$ Saha v. General Medical Council, EWHC 1907 (2009) (U.K.). See also W v. Egdell, 2 WLR 471 (1990) (U.K.).

54 Emily JaCKson, Medical Law: Text, CASES, and Materials 176-7 (4th ed. 2016).

55 Gen. Med. Council, Confidentiality: GOOD PRACTICE IN HANDling PATIENT INFORMATION 18 (2017).
} 
view seems to be that it would not, because normally, in tort law, one is not responsible for the acts of a third party. ${ }^{56}$

In Australia, the Australian courts seem to stop short of clearly imposing a duty to warn non-patients on physicians even though they sometimes stipulate a duty owed by physician to third parties. ${ }^{57}$ In Harvey v. PD, the Court ruled that a doctor breached his common law duty in not providing pre-test counselling when two patients had unprotected sextual intercourse with each other following a joint consultation for HIV screening. ${ }^{58}$ The plaintiff tested HIV-negative, but the doctor denied her access to her then-fiancé's test result (which was HIV-positive). Her then-fiancé lied about his test result to engage in unprotected sexual intercourse with her. ${ }^{59}$ Spigelman CJ stated that the doctor has the duty to advise the plaintiff and her then fiancé of "the need for each to consent to the supply of their results to the other. His failure to do so led to the damage suffered by [the plaintiff] on the basis that if [her then-fiancé] had agreed, she would have been fully informed of his HIV status and if [he] had not agreed, she would have terminated the relationship." 60

One important category of physicians' duty to warn third parties of patients' confidential information concerns genetic data. Numerous scholarly articles on the subject have been written. For the purposes of this article, the author will not discuss it in detail, but will illuminate the same problem that need to be addressed in the duty of confidentiality of physicians in Thailand in the near future. This article will not deal with the relevant professional guidance in other countries or theoretical concepts, such as an argument that the genetic information is shared information ${ }^{61}$, the revelation of which to at-risk genetic relatives is not considered breach of confidence on the part of the doctor. Rather, this article will take pertinent court cases to enlighten the legal duty and uncertainties that Thai doctors may face.

\footnotetext{
${ }^{56}$ HERRING, supra note 36, at 250.

${ }^{57}$ See BT v. Oei NSWSC 1082 (1999) (Austl.). See also BILL MADDEN, Janine Mcilwraith \& Benjamin Madden, Australian Medical LIABILITY 88-9 (3rd ed., 2017).

${ }^{58}$ Harvey v. PD 59 NSWLR 639 (2004) (Austl.).

${ }^{59} \mathrm{Id}$.

${ }^{60} I d$. at 1.

${ }^{61}$ See Anneke Lucassen \& Roy Gilbar, Alerting Relatives about Heritable Risks: The Limits of Confidentiality BMJ 2018 at 361. See also Michael Parker and Anneke Lucassen, Using a Genetic Test Result in the Care of Family Members: How Does the Duty of Confidentiality Apply? 26 EUR. J. OF HuM. GENETICS 955 (2018).
} 


\section{B. Revealing Patients' Genetic Data to Genetic Relatives}

There are no ascertainable reported Australian court cases addressing physicians' duty to patients' genetic relatives. ${ }^{62}$ In the United States, the Supreme Court of Florida ruled that a doctor may owe a duty to children of patients concerning genetically transmissible diseases. ${ }^{63}$ "When the prevailing standard of care creates a duty that is obviously for the benefit of certain identified third parties [in this case, the children of the patient] and the physician knows of the existence of those third parties, then the physician's duty runs to those third parties." 64 However, the Court added: "In any circumstances in which the physician has a duty to warn of a genetically transferable disease, that duty will be satisfied by warning the patient" 65 The Superior Court of New Jersey (Appellate Division), however, declined to follow its Floridian counterpart, holding that it may be necessary that the duty to warn be satisfied by warning the patient's genetic relative directly in cases where the patient insists that nothing be disclosed to family members. ${ }^{66}$

In the United Kingdom, a woman whose father was diagnosed with Huntington's disease, a genetic condition which can be inherited through an autosomal dominant gene (i.e. she had a 50 per cent chance of having the disease given the diagnosis of her father), sued the NHS trust. ${ }^{67}$ She alleged that her father's doctor, who knew of the diagnosis, was negligent in not contradicting her father's preference to warn her of her risk of having Huntington's disease. ${ }^{68}$ She was pregnant at the time of alleged negligence and would have decided to terminate her pregnancy. ${ }^{69}$ Although the Court dismissed the case, finding no breach of duty, it ruled that "it is fair, just and reasonable to impose on the [doctor] a legal duty to the claimant to balance her interest in being informed of her genetic risk against her father's interest in preserving confidentiality in relation to his diagnosis

\footnotetext{
${ }^{62}$ MAdDEN, MCILWRAITH AND MADDEN, supra note 57, at 91.

${ }^{63}$ Pate v. Threlkel, 661 So. 2d 278, 282 (Fla. 1995).

${ }^{64} \mathrm{Id}$.

${ }^{65} \mathrm{Id}$.

${ }^{66}$ Safer v. Estate of Pack, 677 A.2d 1188, 1192-3 (N.J. Super. Ct. App. Div. 1996).

${ }^{67}$ ABC v. St George's Healthcare NHS Trust and others, EWHC 455 (2020)

(U.K.).

${ }^{68} \mathrm{Id}$.

${ }^{69} \mathrm{Id}$.
} 
and the public interest in maintaining medical confidentiality generally." 70

In Australia, even though no court has imposed the duty to warn genetic relatives on physicians, there are guidelines on the use and disclosure of genetic information to a patient's genetic relatives under Section 95AA of the Privacy Act 1988. ${ }^{71}$ Nevertheless, there are arguments over the guideline regarding whether psychological harm to genetic relatives constitutes harm justifying the disclosure to such relatives. ${ }^{72}$ Moreover, some suggest that "there is a practical tendency that once something is made an ethical norm, legal obligations typically follow."73 In other words, once the guidelines are set, the physician's legal duty to disclose to genetic relatives may later ensue even though such guidelines are only permissive rather than prescriptive of the disclosure.

To summarize, the US courts are willing to impose on physician a duty to disclose patients' health data to third parties in certain circumstances. ${ }^{74}$ Likewise, the UK court imposes on doctors a legal duty to third parties to balance their interest in being informed against the patient's interest in preserving confidentiality and the public interest in maintaining medical confidentiality generally. ${ }^{75}$ The medical education and practice in Thailand have been heavily influenced by the US system. ${ }^{76}$ While Thailand is a civil law jurisdiction, Thai courts generally employ the adversarial system because the court system was modernized and westernized by many UK-educated scholars, including Prince Raphi ${ }^{77}$. Accordingly, it is likely that Thai

\footnotetext{
${ }^{70} \mathrm{Id}$. at 188.

71 National Health and Medical Research Council, Use AND DiSClOSURE OF GENETIC INFORMATION TO A PATIENT'S GENETIC RELATIVES UNDER SECTION 95AA OF THE PRIVACY ACT 1988 (CTH) (2014).

${ }^{72}$ Rebekah McWhirter, Carolyn Johnston and Jo Burke, Disclosure of Genetic Results to At-Risk Relatives without Consent: Issues for Health Care Professionals in Australia. 27 J. OF L. AND MED. 108, 114-8 (2019).

${ }^{73}$ Margaret Otlowski \& Lisa Eckstein, Genetic Privacy in TENSIONS AND Traumas in Health Law 289 (Ian Freckelton \& Kerry Petersen eds., 2017).

${ }^{74}$ See Pate v. Threlkel, 661 So. 2d 278, 282 (Fla. 1995); Safer v. Estate of Pack, 677 A.2d 1188, 1192-3 (N.J. Super. Ct. App. Div. 1996); Tarasoff v. Regents of University of California, 17 Cal. 3d 425 (1976).

${ }^{75} \mathrm{ABC}$, EWHC 455, at 188 .

${ }^{76}$ Khajorndej Direksoonthorn, ความยินยอมที่ได้รับการบอกกล่าวในบริบทของระบบกฎหมายไทย: เรื่องที่ศาลต้องวางหลักในอนาคตอันใกล้ [Informed Consent in Thai Legal System: The Urgent Matter Requiring the Court's Attention] 66 คุลพาห [J. OF THE OFF. OF THE JUDICIARY OF THAI.] 120, 123 (2019).

77 พระบิดาแห่งกฎหมายไทย [The Father of the Thai Law], เนติบัณฑิตยสภา [THE THAI

BAR], http://www.thethaibar.or.th/thaibarweb/index.php/th/องค์กร/เนติบัณฑิตยสภา/
} 
courts may impose such a duty on physicians in Thailand in the future.

While it is unclear when and whether Thai courts will impose on doctors the duty to disclose, inconsistencies and uncertainty over conflicting statutes should still be ameliorated. Guidance should be clarified to allow doctors to divulge patients' health data to protect the public interest without fear of criminal or and civil liability.

\section{The MOPH's Regulation on the Protection and Management of Personal Health Data: The Legal Instrument Only to Confuse the Issue}

The Ministry of Public Health of Thailand (MOPH) enacted the 'Regulation on the Protection and Management of Personal Health Data, B.E. 2561 (2018),' only to confuse the issue. This Regulation pertains to the disclosure of health data held by all entities under the control of the Ministry of Public Health. ${ }^{78}$ Article 13 of the Regulation reads: "Personal health data is personal confidential information which can be disclosed only if the data subject's consent is given or it is required by law. In any event, the disclosure must not cause damage to the data subject. ${ }^{79}$ (Emphasis added.) The last sentence causes confusion to physicians again, especially when disclosure to third parties would conflict with patients' own preference. Divulging confidential information in contradiction of patients' selfdetermination when the public interest in protecting others outweighs the interests of confidentiality (generally and of the patient) may unavoidably be deemed as causing damage to the patient or data subject. As a consequence, strictly following the Regulation will preclude any disclosure in favor of the public interest that runs afoul of the patient's own interest if they decline to consent to such disclosure. Another problem is that this Regulation may be in contravention of the Official Information Act, which also governs the disclosure of health data

พระบิดาแห่งกฎหมายไทย.html (Prince Raphi, who is known as Father of Thai Modern Legal System, studied at Oxford and came back to Thailand in order to establish the westernized court system employing an adversarial system.). ${ }^{78}$ See also Asia Pacific Observatory on Health Systems and Policies, The Kingdom of Thailand Health System Review, HEALTH SYSTEMS IN Transition, Vol. 5 No. 5 at 38 (2015) (In 2008, some 77\% of hospitals in Thailand were public, the vast majority owned by the MOPH, a few by other ministries.).

79 The Ministry of Public Health's Regulation on the Protection and Management of Personal Health Data, B.E. 2561 Article 13 (2018) (Thai.). 
possessed by the MOPH. The Official Information Act permits "the disclosure necessary for the prevention or elimination of harm to the life or health of persons." ${ }^{80}$ Under the Official Information Act, the harm which can justify the disclosure to third parties need not even be imminent or serious. ${ }^{81}$ Disclosure when there are no imminent or serious threats to third parties may be deemed as causing damage to the patient or data subject, therefore prohibited by the MOPH's Regulation.

In even starker contrast to the MOPH's Regulation is the Mental Health Act. That Act permits the disclosure of health information of patients suffering from mental disorder(s) where harm may be caused to the patient or to others, even if the disclosure may cause damage to the patient. ${ }^{82}$ For example, they may be restrained or even arrested.

\section{Resolving the Conflicts of HeAlth DAta Protection LAWS: GAINING THE PERSPECTIVES FROM AUSTRALIA AND EUROPE}

To illuminate this important issue in Thailand, it is worth considering how Australian and European laws deal with it.

\section{A. Australia's Privacy Act 1988 (Cth)}

The Privacy Act 1988 (Cth) sets out thirteen Australian Privacy Principles (APPs) which regulate the management, collection, storage, use, disclosure, correction and integrity of, and access to personal information. ${ }^{83}$ Health and genetic information are categorized as sensitive information, a subset of

\footnotetext{
${ }^{80}$ Official Information Act, B.E. $2540 § 24(7)$ (1997) (Thai.).

81 This contention is because of how this provision is framed. Unlike Section 67 and 68 of the Thai Criminal Code, the provision is framed in a manner that excludes the requirements of imminent or serious harm. The contention also corresponds with the Select Parliamentary Committee of the Personal Data Protection Bill's interpretation of the similar provisions of the Personal Data Protection Act having been framed in the same manner. The Committee has suggested that a danger to life, body or health of the Person need not be imminent, nor the situation be urgent to constitute the permitted situation. See Nat'L Assembly of Thai. Select Parliamentary Comm., RePort on the Personal Data Protection Act Presented to the Parliament, $2 \mathrm{~d}$ reading, at 21 [2019] (Thai.).

${ }^{82}$ Mental Health Act, B.E. $2551 \S 16$ (2008) (Thai.) (No person shall disclose health information of a patient in such a way that is likely to cause damage to the patient, except: (1) in a case where harm may be caused to the patient or to others....).

${ }^{83}$ Privacy Act 1988 (Cth) Schedule 1 (1988) (amended 2020) (Austl.).
} 
personal information. ${ }^{84}$ The permitted general situations in relation to the collection, use, or disclosure of personal information are enumerated in Section 16A of the Privacy Act $1988 .{ }^{85}$ Item 1 of Section 16A permits disclosure of personal information if it is unreasonable or impracticable to obtain the individual's consent to the disclosure and the relevant entity reasonably believes that the disclosure is necessary to lessen or prevent a serious threat to the life, health or safety of any individual, or to public health or safety. ${ }^{86}$ As a result, doctors in Australia can disclose personal information (including health information) of patients in cases where psychiatrists encounter situations similar to that in Tarasoff due to it being unreasonable to obtain the patient's consent to the psychiatrist's disclosure to law enforcement or potential victim(s), and the doctor reasonably believes that such disclosure is necessary to lessen or prevent a serious threat to the life, health or safety of potential $\operatorname{victim}(\mathrm{s})$.

Section 16B of the Privacy Act 1988 further sets out permitted situations in relation to the collection, use or disclosure of health information. ${ }^{87}$ Paragraph 4 of Section 16B specifies the use or disclosure of genetic information to a genetic relative. ${ }^{88}$ If genetic information was obtained in the course of providing health services to patients and doctors believe that disclosure is necessary to lessen or prevent a serious threat to the life, health or safety of another individual who is a genetic relative of the patient, such disclosure to the genetic relative is permitted provided it is conducted in accordance with guidelines approved under Section 95AA. ${ }^{89}$ The Australian National Health and Medical Research Council issued the guidelines in 2009. ${ }^{90}$

\footnotetext{
${ }^{84} I d$. at $\S 6$ (definition of personal information and sensitive information.).

${ }^{85} I d$. at $\$ 16 \mathrm{~A}$.

${ }^{86} \mathrm{Id}$.

${ }^{87} \mathrm{Id}$. at $\S 16 \mathrm{~B}$.

${ }^{88} \mathrm{Id}$.

${ }^{89} I d$. at $\S 95 \mathrm{AA}((1)$ This section allows the Commissioner to approve for the purposes of the Australian Privacy Principles guidelines that are issued by the National Health and Medical Research Council. (2) For the purposes of paragraph $16 \mathrm{~B}(4)(\mathrm{c})$, the Commissioner may, by legislative instrument, approve guidelines that relate to the use and disclosure of genetic information for the purposes of lessening or preventing a serious threat to the life, health or safety of an individual who is a genetic relative of the individual to whom the genetic information relates).

${ }^{90}$ National HeAlth AND MedicAl ReSEARCH Council, supra note 71, at 5.
} 


\section{B. The GDPR}

The European Union (EU) regulation 2016/679 on the protection of natural persons with regard to the processing of personal data, also known as the General Data Protection Regulation (GDPR), has been in force since 25 May 2018. ${ }^{91}$ The GPDR repealed the previous EU directive on data protection (Directive 95/46/ EC). ${ }^{92}$ "It was first proposed in 2012 to establish a uniform set of rules that would provide enhanced protection for EU citizens, foster innovation in the European Single Market and make the EU, according to Commissioner Jourova, 'fit for the digital age' (European Commission, 2015)."93

As Bennett argues, the GDPR has played three roles: "instruments of harmonization, exemplars, and a coercive force." 94 Thailand has used the GDPR as a starting point in drafting a new law, evidenced by the many commonalities shared by the two data protection regimes. Thailand has also been affected by "the global awareness that has been sparked by the apparent extra-territorial applicability of the GDPR - the law attempts to regulate organizations based outside the EU which supply products or services to EU citizens, even where such [Thai] organizations have no EU presence or establishment." 95 However, this should not surprise or unnecessarily worry the Thai government and people as the GDPR is applicable in all countries. Even in the United States, US organizations that wish to transfer personal data involving EU citizens must be certified as having met "the 'Privacy Shield' framework established by the EU and the US Department of Commerce. Certification signals that the US entity complies with the GDPR's privacy principles, breaches of which are enforceable in the US via the

\footnotetext{
${ }^{91}$ Regulation 2016/679, of the European Parliament and of the Council of 27 April 2016 on the protection of natural persons with regard to the processing of personal data and on the free movement of such data, and repealing Directive 95/46/EC, 2016 O.J. (L 119).

92 Luca Marelli and Giuseppe Testa, Scrutinizing the EU General Data Protection 360 SCIENCE 496, 496 (2018).

${ }^{93}$ Colin J Bennett, The European General Data Protection Regulation: An Instrument for the Globalization of Privacy Standards? 23 INFORMATION POLITY 239, 240 (2018).

${ }^{94}$ Id. at $243-4$.

95 Peter Carey, Data Protection: A Practical Guide to UK and EU LAW at xxxiv (5th ed. 2018).
} 
Federal Trade Commission (FTC) and the US Department of Transportation." 96

\section{The Personal Data Protection Act: GDPR-Style Law, A HOPE FOR THAI PHYSICIANS?}

Physicians in Thailand may warmly welcome the advent of the Personal Data Protection Act, B.E. 2562 (2019) as a clarification on the confusing field. This Act has passed in the Thai Parliament after over twenty years of Thai Governmental efforts to propose a personal data protection law. ${ }^{97}$ The Act is a piece of $G D P R$-style data protection legislation. ${ }^{98}$ It is also Thailand's first general data protection law which governs both the public and private sectors with some organizations and activities exempted from the Act's provisions. ${ }^{99}$ The Act provides for personal data protection ${ }^{100}$, rights of data subjects ${ }^{101}$, the process for lodging complaints ${ }^{102}$, including stipulating civil ${ }^{103}$, criminal $^{104}$, or administrative liability ${ }^{105}$ of a data controller and data processor. A court may impose punitive damages on violators. ${ }^{106}$ Importantly, the Act establishes the permanent Personal Data Protection Committee. ${ }^{107}$ Under the Act, the Committee shall then appoint one or more Expert Committees based upon their fields of expertise. ${ }^{108}$ The Expert Committees are charged with considering complaints under the Act and investigating any act of data controllers or data processors, including employees or contractors of data controllers or data processors in connection with the personal data that caused damage to a data subject. ${ }^{109}$

\footnotetext{
96 Nathan Cortez et al, ReAdings in Comparative HeAlth LAW AND BIOETHICS at 210 (3rd ed. 2019).

${ }^{97}$ Piyabuth Boonaramrung et al, Thailand data protection guidelines 2.0: แนว ปฏิบัติเกี่ยวกับการคุ้มครองข้อมูลส่วนบุคคล 16 (2019).

${ }^{98} \mathrm{Id}$.

${ }^{99}$ Personal Data Protection Act, B.E. $2562 \S 4$ (2019) (Thai.).

${ }^{100}$ Personal Data Protection Act, B.E. 2562 Chapter II (2019) (Thai.).

${ }^{101}$ Personal Data Protection Act, B.E. 2562 Chapter III (2019) (Thai.).

102 Personal Data Protection Act, B.E. 2562 Chapter V (2019) (Thai.).

${ }^{103}$ Personal Data Protection Act, B.E. 2562 Chapter VI (2019) (Thai.).

104 Personal Data Protection Act, B.E. 2562 Chapter VII Part I (2019) (Thai.).

105 Personal Data Protection Act, B.E. 2562 Chapter VII Part II (2019) (Thai.).

106 Personal Data Protection Act, B.E. $2562 \S 78$ (2019) (Thai.).

${ }^{107} \mathrm{Id}$. at $\S 8$.

${ }^{108} I d$. at $\S 71$.

${ }^{109} I d$. at $§ 72$.
} 
This Act should have come into force on 27th May 2020. ${ }^{110}$ However, the rules, procedures and conditions required by the Act are detailed and complex. Due to the advanced technology needed to protect personal information as effectively as the Act's objectives demand, a large number of data controllers, governmental and private agencies, and businesses nationwide, were not ready to comply with the Act at the time. Therefore, the Thai Government enacted a royal decree, exempting data controllers of specified agencies and business from the Personal Data Protection Act during the one-year period. ${ }^{111}$ Public and private sector entities responsible for medical and public health affairs are among those exempted from enforcement of the Act by virtue of said royal decree until 1st June 2021. ${ }^{112}$ Thus, the health data governance in Thailand set forth by the Act will come into force on $1^{\text {st }}$ June 2021 barring further postponement of the effective data by the Thai Government.

Even though the Personal Data Protection Act, B.E. 2562 (2019) has yet to become effective with regard to personal health data in Thailand, it is worth considering its implications for health data governance in Thailand. Once it comes into force, it will arguably become the most comprehensive and significant piece of legislation on personal data protection which governs data held by both the public and private sectors. ${ }^{113}$ This article

\footnotetext{
110 Personal Data Protection Act, B.E. 2562 § 2 (2019) (Thai.) (The act reads as follows, "This Act shall come into force on the day following the date of its publication in the Government Gazette, except for the provisions of Chapter II, Chapter III, Chapter V, Chapter VI, Chapter VII, and section 95, and section 96, which shall come into effect after the lapse of a period of one year from the date of its publication in the Government Gazette." The Act was published in the Government Gazette on May 27 ${ }^{\text {th }}, 2019$.).

${ }^{111} I d$. at $\S 4$ (The exceptions to apply all or parts of the provisions of this Act to any Data Controller in any manner, business or entity, in a similar manner to the Data Controller in paragraph one, or for any other public interest purpose, shall be promulgated in the form of the Royal Decree.).

112 See Royal Decree Specifying the Businesses or Entities Whose Data Controllers Are Exempt from the Provisions of the Personal Data Protection Act, B.E. $2563 \S \S 2,3$ (2020) (Thai.); the Schedule Annexed to the Royal Decree Specifying the Businesses or Entities Whose Data Controllers Are Exempt from the Provisions of the Personal Data Protection Act, B.E. 2563 (2020) (Thai.).

113 Personal Data Protection Act, B.E. $2562 \S 3$ (2019) (Thai.) (In the event that there is any sector-specific law governing the protection of Personal Data in any manner, any business or any entity, the provisions of such law shall apply, except: (1) for the provisions with respect to the collection, use, or disclosure of Personal Data and the provisions with respect to the rights of data subjects including relevant penalties, the provisions of this Act shall
} 
will turn to how the Act handles the problem of the duty of Thai physicians to third parties as discussed above.

Sections $26^{114}$ and $27^{115}$ of the Act prohibit any collection, use or disclosure of personal health and genetic data without the explicit consent from the data subject. However, Section 26 sets forth the situations and criteria in which such collection, use or disclosure are permitted without any consent from the data subject. ${ }^{116}$ According to Section 26 (1), collection, use or disclosure is permitted to prevent or suppress a danger to life, body or health of the Person, when the data subject is incapable of giving consent for whatever reason. ${ }^{117}$ This subsection, therefore, permits the doctor to disclose health or genetic information only when the data subject is incapable of giving consent whether physically or legally, but not when the data subject deliberately refused such consent. Hence, doctors in Thailand cannot invoke this provision to disclose the patient's genetic information to their genetic relatives when the patient does not consent. It should also be noted that, the Select Parliamentary Committee of the Bill has suggested that a danger to life, body or health of the Person need not be imminent, nor the situation be urgent to constitute the permitted situation. ${ }^{118}$ The Select Parliamentary Committee also suggested that the Personal Data Protection Committee, established by the Act and charged with the power to interpret and render rulings with respect to the issues arising from the enforcement of the Act, ${ }^{119}$ should follow its interpretation because that is the Act's

apply additionally, regardless of whether they are repetitious with the above specific law...).

114 Personal Data Protection Act, B.E. $2562 \S 26$ (2019) (Thai.) (“Any collection of Personal Data pertaining to...health data...genetic data...is prohibited, without the explicit consent from the data subject, except where....").

${ }^{115} I d$. at $\S 27$ ("The Data Controller shall not use or disclose Personal Data without the consent of the data subject, unless it is the Personal Data which is collected without requirement of consent under section 24 or section 26."). ${ }^{116} \mathrm{Id}$. at $\S 26$ (Any collection of Personal Data pertaining to racial, ethnic origin, political opinions, cult, religious or philosophical beliefs, sexual behavior, criminal records, health data, disability, trade union information, genetic data, biometric data, or of any data which may affect the data subject in the same manner, as prescribed by the Committee, is prohibited, without the explicit consent from the data subject, except where...).

${ }^{117} I d$. at $\S 6$ (Defines "Person" as a natural person.).

118 NAT'L Assembly OF Thai. SElECt Parliamentary COMM., REPORT ON the Personal Data Protection Act Presented to the Parliament, $2 \mathrm{~d}$ reading, at 21 (2019) (Thai.).

119 Personal Data Protection Act, B.E. $2562 \S 16$ (2019) (Thai.). 
objective. ${ }^{120}$ The interpretation that a danger to life, body or health of the Person need not be imminent is also congruent with the provision of the Official Information Act that allows, even without the data subject's consent, "the disclosure necessary for the prevention or elimination of harm to the life or health of persons." 121

Another relevant provision that merits discussion is Section 26(5)(b). It is a permitted situation in which disclosure of health or genetic data can be made without the consent from the data subject if "it is necessary for compliance with a law to achieve the purposes with respect to public interest in public health, such as protecting against cross-border dangerous contagious disease or epidemics which may be contagious or pestilent, or ensuring standards or quality of medicines, medicinal products or medical devices, on the basis that there is a provision of suitable and specific measures to safeguard the rights and freedom of the data subject, in particular maintaining the confidentiality of personal data in accordance with the duties or professional ethics." ${ }^{122}$ Some may argue that disclosing patients' genetic information to genetic relatives can protect them by allowing them to seek early diagnosis, prophylactic treatment/surgery or at least close surveillance for that particular genetically inherited disease. As such, it achieves the purposes with respect to public interest in public health, thereby constituting a permitted situation under this provision. However, such argument is untenable. Providing patients' health information to others so as to protect particular persons is not within the ambit of the public interest in public health. The Court of Appeals of New York, the highest court in the State of New York, handed down a decision that can illuminate the interpretation of this aspect of Thai law.

In the United States, 'the Health Insurance Portability and Accountability Act of 1996 (HIPAA) ${ }^{123}$ required the Secretary of Health and Human Services to issue rules improving privacy protections.' 124 The Secretary of Health and Human Services then issued federal privacy regulations (the 'Privacy Rule') ${ }^{125}$ to maintain the confidentiality of defined

\footnotetext{
${ }^{120}$ NAT'L ASSEMbly OF Thai. SElECt PARLIAMENTARY COMM., supra note 118 , at 22 .

${ }^{121}$ Official Information Act, B.E. $2540 \S 24$ (1997) (Thai.).

122 Personal Data Protection Act, B.E. $2562 \S 26(5)(b)$ (2019) (Thai.).

${ }^{123}$ Health Insurance Portability and Accountability Act of 1996, Pub. L. No. 104-191, 110 Stat. 1936 (1996).

${ }^{124}$ HALL, BOBINSKI \& ORENTLICHER, supra note 4, at 172.

12545 C.F.R. $\S \S 160 \& 164$.
} 
types of protected health information, subject to some exceptions. ${ }^{126}$ The Privacy Rule has been an attempt to establish a comprehensive set of rules governing the confidentiality of medical records and relevant individually identifiable health information. ${ }^{127}$ Generally speaking, the Privacy Rule forbids disclosure of health information without patient authorization. It preempts conflicting state laws unless those state laws are more stringent. ${ }^{128}$ In the Matter of Miguel M v. Barron, a case where the Privacy Rule was the applicable law, the Court of Appeals of New York held, "apparent purpose of the public health exception [to the Privacy Rule] is to facilitate government activities that protect large numbers of people from epidemics, environmental hazards, and the like, or that advance public health by accumulating valuable statistical information. To disclose private information about particular people, for the purpose of preventing those people from harming themselves or others, effects a very substantial invasion of privacy without the sort of generalized public benefit that would come from, for example, tracing the course of an infectious disease." ${ }^{129}$ The author of this article agrees with that decision's interpretation and proposes applying it to the Thai equivalent provision. To construe the "public health" exception as including disclosure of the health or genetic data to third parties would be a stretch and indefensible.

Another provision closely related to the issue of disclosure to third parties without patient consent is Section 26(5)(a). It provides for another situation in which health and genetic data can be collected, used, or disclosed to third parties if "it is necessary for compliance with a law to achieve the purposes with respect to preventive medicine or occupational medicine, the assessment of working capacity of the employee, medical diagnosis, the provision of health or social care, medical treatment, the management of health or social care systems and services." 130 (Emphasis added.) One may argue that proper medical diagnosis and treatment as well as the provision of health or social care compel doctors to disclose the patients' health or genetic data to third parties even if patients refuse to

\footnotetext{
${ }^{126}$ HALL, BOBINSKI \& ORENTLICHER, supra note 4, at 172.

${ }^{127}$ CORTEZ ET AL, supra note 96, at 209; See generally Jeremy Shapiro-Barr, The GDPR's Impact in the U.S.: Considerations for the U.S. Health Lawyer, 12 J. OF HEALTH AND LIFE SCI. L. 39 (2018) (comparison between HIPAA and the GDPR).

${ }^{128}$ In the Matter of Miguel Mv. Barron, 950 N.E.2d 107, 110 (N.Y., 2011).

${ }^{129} \mathrm{Id}$. at 111.

${ }^{130}$ Personal Data Protection Act, B.E. $2562 \S 26(5)(a)$ (2019) (Thai.).
} 
give consent. The problem with that argument is it cannot be said that such disclosure is necessary for complying with a law. Except for the duty concerning notifiable diseases or child abuse, no other Thai law imposes a duty of such disclosure on physicians. ${ }^{131}$ The Mental Health Act merely permits disclosure of health information of patients suffering from mental disorder(s) to protect third parties ${ }^{132}$; it does not obligate the doctor to disclose the information. This Section is a direct derivation from the GDPR, evidenced by the near word-for-word translation of the equivalent GDPR provision into Thai. However, upon the passage in Thailand, the provision was framed differently from the original GDPR provision. The direct result was that doctors were not permitted to disclose health data to third parties for the sake of public interest in others' safety and welfare as discussed in this article.

To illustrate, Article 9 paragraph 1 of the GDPR prohibits the processing of genetic data and data concerning health. ${ }^{133}$ However, paragraph 2 (h) sets out a permitted situation in which the processing ${ }^{134}$ of such data is necessary for the purposes of preventive or occupational medicine, for the assessment of the working capacity of the employee, medical diagnosis, the provision of health or social care or treatment or the management of health or social care systems and services on the basis of Union or Member State law or pursuant to contract with a health professional and subject to the conditions and safeguards referred to in paragraph $3 .{ }^{135}$ This provision, from which the Thai equivalent is derived, merely lays down the permitted situation in which the physician, as a professional subject to the obligation of professional secrecy for the purposes

\footnotetext{
${ }^{131}$ Sathirareuangchai, supra note 1 , at 80 .

132 Mental Health Act, B.E. $2551 \S 16$ (2008) (Thai.) (No person shall disclose health information of a patient in such a way that is likely to cause damage to the patient, except: (1) in a case where harm may be caused to the patient or to others; (2) for the safety of the public...).

${ }^{133}$ Regulation 2016/679, of the European Parliament and of the Council of 27 April 2016 on the protection of natural persons with regard to the processing of personal data and on the free movement of such data, and repealing Directive 95/46/EC, 2016 O.J. (L 119) art. 9 para. 1.

${ }^{134} I d$. at art. 4 para. 2 (processing includes use and disclosure by transmission, dissemination or otherwise making available.).

${ }^{135} \mathrm{Id}$. at art. 9 paras. 2, 3. (Personal data referred to in paragraph 1 may be processed for the purposes referred to in point $(\mathrm{h})$ of paragraph 2 when those data are processed by or under the responsibility of a professional subject to the obligation of professional secrecy under Union or Member State law or rules established by national competent bodies or by another person also subject to an obligation of secrecy under Union or Member State law or rules established by national competent bodies.).
} 
of paragraph 3's conditions and safeguards, may disclose the genetic data or data concerning health to third parties on the basis of Union or Member State law. On the contrary, Section 26(5)(a) of the Thai Personal Data Protection Act is framed in a problematic way. The permitted situation under that Section is: 'it is necessary for compliance with a law to achieve the purposes with respect to .... ${ }^{136}$ No Thai laws necessitate doctors disclosing patients' health information to third parties except as to notifiable diseases or child abuse. ${ }^{137}$ It is likely that, even when the Act comes into force next year, doctors in Thailand will not be able to disclose health or genetic data to third parties in the public interest without the explicit consent from the data subject under Section 26(5)(a) of the Personal Data Protection Act.

In sum, it is doubtful that the Personal Data Protection Act will successfully offer Thai physicians safe harbor when disclosing patient data to third parties for the reasons the article has discussed. The article next proposes the resolution of the matters.

\section{PRoposals to AMEND THE LAWS AND DEVELOP GUIDELINES}

This article proposes amendments to the National Health Act and the MOPH's Regulation. The last sentence of Section 7 of the National Health Act stating: "In any case whatsoever, no person shall have the power or right under the law on official information or other laws to request a document related to personal health information of any person other than himself or herself' should be jettisoned to eliminate the inconsistency with other Acts as described above. Likewise, the last sentence of Article 13 of the MOPH's Regulation on the Protection and Management of Personal Health Data, B.E. 2561 (2018) stating: 'In any event, the disclosure must not cause damage to the data subject.' should be omitted to eliminate confusion about whether disclosure of health data to third parties without consent or with explicit refusal from the patient is permitted.

These amendments will eliminate confusion arising from the conflicts with other legislation. The duty to warn third parties, however, should accord with professional guidance. A scarcity of such professional guidance in Thailand troubles and demands doctors to exercise discretion and professional

\footnotetext{
${ }^{136}$ Personal Data Protection Act, B.E. $2562 \S 26(5)$ (a) (2019) (Thai.).

${ }^{137}$ Sathirareuangchai, supra note 1 , at 80.
} 
judgement at their own risk. Furthermore, contradicting internal policies of different institutions created an inconsistent health data protection regime in Thailand that is difficult for doctors to implement thoughtfully with appropriate good judgement. The criteria, conditions, and relevant factors that justifies disclosure should be incorporated into the guidelines. In the United Kingdom, for instance, the General Medical Council (GMC) has issued guidance for doctors entitled 'Confidentiality: good practice in handling patient information.' ${ }^{138}$ It has been regularly updated, the latest of which was on 25 May 2018 to reflect the requirements of the GDPR and the UK's Data Protection Act $2018 .{ }^{139}$ It sets out the "framework for considering when to disclose patients' personal information and then applies that framework to: a disclosure to support the direct care of an individual patient, $\mathrm{b}$ disclosures for the protection of patients and others, and c disclosures for all other purposes." 140 The Medical Council of Thailand (TMC) should adopt the practice of issuing clear guidelines for doctors on this matter to avoid the onerous task of developing clear and detailed guidelines whenever a novel situation arises.

Developed by the Australian NHMRC, guidelines on use and disclosure of genetic information to a patient's genetic relatives has been criticized for its inclusion of psychological harm of the patient's relatives as a condition justifying disclosure without consent. ${ }^{141}$ Additionally, there is uncertainty about the extent to which Australian health care professionals in general will adopt such NHMRC guidelines since only those in private practice are legally bound by the guidelines. ${ }^{142}$ "The Australian Privacy Principles (APPs) do not apply to State and Territory public hospitals, other public agencies and prescribed instrumentalities, as they do not fall within the definition of 'organisation' in the Privacy Act 1988 (Cth)." ${ }^{143}$ The latter issue will not occur in Thailand, as the TMC has the authority to issue guidelines governing all physicians practicing in Thailand, whether public or private. The TMC should issue guidelines concerning psychological harm and may consult the Royal Colleges of Physicians and Psychiatrists of Thailand when it establishes a working group on developing detailed guidelines.

\footnotetext{
138 Gen. Med. COUNCIL, CONFIDENTIALITY: GOOD PRACTICE IN HANDLING PATIENT INFORMATION (2017).

${ }^{139} I d$. at 1.

${ }^{140} I d$. at 8.

${ }^{141}$ McWhirter, Johnston \& Burke, supra note 72 , at 114-8.

${ }^{142} \mathrm{Id}$. at 114 .

${ }^{143}$ White, MCDONALD \& WiLLMOTT, supra note 6, at 413.
} 
Thai authorities should also refer to other countries' experiences concerning disclosure to third parties in general. Moreover, providing doctors with relevant guidelines on disclosing health information to third parties will convey a message to Thai doctors that the duty of confidentiality to the patient is not absolute. Contrary to that message, certain existing literature on medical litigation in Thailand warns against any disclosure of patients' health information to third parties. ${ }^{144}$ Some claim that doctors who disclose patients' health information put themselves at risk of violating Section 323 of the Thai Criminal Code. ${ }^{145}$ This misconception underlines the need for clear guidance from the TMC. These guidelines should be applied flexibly and pragmatically under the relevant circumstances.

Even though the Personal Data Protection Act has yet to come into force for the matter discussed, its relevant provision is problematic. Section 26(5)(a), which outlines a situation in which health and genetic data can be used or disclosed to third parties if "it is necessary for compliance with a law to achieve the purposes with respect to preventive medicine or occupational medicine...medical diagnosis... medical treatment...", should be amended to add professional guidelines as a source of authority the doctor can invoke to disclose data. Currently, no law other than those on child abuse or notifiable diseases obligate the doctor to disclose genetic or health data to third parties. To illustrate, the provision can be rewritten as "if it is necessary for compliance with a law or relevant professional guidelines established by national professional bodies to achieve the purposes of..." Needless to say, even if the provision is rewritten, it would still be necessary to amend the other discussed provisions. The Personal Data Protection Act is an addition to the existing Thai data protection legislation; it sets a minimum standard of personal data protection. ${ }^{146}$ Hence, if other

144 Prateep AowwichitKun, พืองแพทย์ [SUING THE DoctoR] 201 (4th ed. 2019).

${ }^{145}$ Criminal Code, $\S 323$ (amended in 2017) (Thai.) (Whoever, knows or acquires a private secret of another person by reason of his functions as a competent official or his profession as a medical practitioner, pharmacist, druggist, midwife, nurse, priest, advocate, lawyer or auditor, or by reason of being an assistant in such professions, and then discloses such private secret in a manner likely to cause injury to any person, shall be punished with imprisonment not exceeding six months or fined not exceeding ten thousand baht, or both.)

${ }^{146}$ Personal Data Protection Act, B.E. $2562 \S 3$ (2019) (Thai.) (In the event that there is any sector-specific law governing the protection of Personal Data in any manner, any business or any entity, the provisions of such law shall apply, except: 
legislations are not amended as suggested, inconsistencies among various laws would still be a problem since those laws' standards of data protection are higher than that of the Personal Data Protection Act and are thus arguably still intact and not modified by the Personal Data Protection Act. This may result in a strict prohibition on health and genetic data disclosure to third parties, regardless of the circumstance.

\section{CONCLUSION}

The right to personal data is currently enshrined in the Constitution of Thailand. This fact, on the one hand, reflects the importance of personal data protection, to the point of recognition in the supreme law of the land. On the other hand, it may cause Thai physicians concern and even misconception regarding the disclosure of the patients' personal health data to third parties.

The Australian Government's Department of Health and Ageing once stated: "The co-existence of Commonwealth, state and territory health information privacy legislation has created a significant burden on [private sector] health care services in understanding and meeting respective obligations, as well as confusion for health consumers affected by dual legislative instruments." ${ }^{147}$ Even though Thailand is a unitary state in which legislative acts govern throughout, that statement is equally suited to the current situation. The inconsistencies either within

(1) for the provisions with respect to the collection, use, or disclosure of Personal Data and the provisions with respect to the rights of data subjects including relevant penalties, the provisions of this Act shall apply additionally, regardless of whether they are repetitious with the above specific law;

(2) for the provisions with respect to complaints, provisions granting power to the expert committee to issue an order to protect the data subject, and provisions with respect to the power and duties of the Competent Official, including relevant penalties, the provisions of this Act shall apply in the following circumstances:

(a) in the event that such law has no provision with respect to complaints;

(b) in the event that such law has the provisions giving the power to the competent official, who has the power to consider the complaints under such law, to issue an order to protect the data subject, but such power is not equal to the power of the expert committee under this Act; and either the competent official who has power under such law makes a request to the expert committee, or data subject files a complaint with the expert committee under this Act, as the case may be.).

147 Australian LAW REFORM COMMission, Vol. 3 Report 108, AUSTRALIAN PRIVACY LAW AND PRACTICE 323 para. 60.20 (2008). 
the same piece of legislation or with other laws governing the same matter of health data protection have engendered confusion and worry to physicians. Particularly, disclosure of patients' health data to protect others, including genetic relatives is the primary focus of this article.

This article has argued in favor of amendments to existing laws to eliminate such contradictions. The new Personal Data Protection Act also needs modifications to clarify potential civil and criminal liability for physicians. Furthermore, the article urges the Medical Council (TMC) to develop guidelines on the disclosure of such data to third parties. Those guidelines should be incorporated into the conditions for disclosure under the Personal Data Protection Act's regime. 